\title{
The Effects of the Ports and Water Transportation on the Aquatic Ecosystem
}

\section{Mesut Selamoglu*}

\section{Osmaniye Korkut Ata University, Bahce Vocational School, Department of Management and Organization, Logistics Pro-} gramme, Bahce, Osmaniye, Turkey.

*Corresponding author: Mesut Selamoglu, Osmaniye Korkut Ata University, Bahce Vocational School, Department of Management and Organization, Logistics Programme, Bahce, Osmaniye, Turkey.

\section{ABSTRACT}

Most of economic and industrial actions have completely impact on nature. Aquatic ecosystems are subject to different environmental impacts originating from human activities in water and/or on land. Oceans around the world are impacted by environmental degradation due to garbage pollution generated by ships. The most important of these globally increasing anthropogenic pressures is created by the waterborne transport of cargo and passengers. Water transportation has many effects on the environment. There are various environmental and ecological effects of shipping. In ports, the aquatic ecosystems and living organisms suffer from environmental impact by emissions of volatile organic substances, and pollution of water by oil chemicals and many various hazardous agents. This paper has been focused on the environmental issues in ports and their negative environmental impact on the aquatic ecosystems.

Keywords: Aquatic ecosystems, Environmental pollution, Water transportation, Ports

\section{Introduction}

For all kinds of transportation, including water transportation, the construction of a balance between economic and ecological interests will be the most critical issue for the next decade. Any type of commercial or industrial activity has an impact on the environment. Noise, aromas, volatile organic compounds, and pollution of water and soil by oil chemicals, hull paint, and other hazardous materials all have a negative impact on the environment in ports [1]. The approaches of integrated emission inventories [2] based on sources common nomenclature [3] can be used to characterise the environment of port regions. The creation of integrated emissions inventories in port regions allows for the characterization of the varied roles played by various emission sources in various environmental media, and thus serves as a fundamental instrument for defining environmental quality control requirements.

Point sources (the primary industrial and commercial sources), linear sources (the main transportation network), and distributed sources are the three types of sources (all the other sources). The use of pollutant release and transfer registers in the creation of inventories from point sources is beneficial $[4,5]$. It is possible to estimate the emissions for industrial point sources based on this documentation. To estimate pollution emissions from linear sources, traffic census data and emission factors, or more complicated models, are utilised (road, river, railway, seaway).

A statistical treatment of information is required when dealing with scattered sources. These sources are assessed on a geographical level, inside each district or area, and then spatially disaggregated into smaller meshes. Distributed sources are defined as data collected from literature or local data on appropriate activity indicators (paint consumption, gasoline consumption, etc.) utilising statistics and ad hoc enquiries, as well as appropriate emission factors (in mass for activity indicators units). Finally, specialised models can be used to analyse emissions estimates in specific domains (road traffic, airports, vegetation, forest fires) [6].

This study discusses a number of various environmental problems related to port activities. The significant factors such as port location, contraction and operations play an important function on the environmental impacts of ports. Some of the environmental problems caused by port 
activities are related to specific types of ships or cargo. Impact from loading and unloading and moving goods in the port area differs somewhat between the different types of cargo. The port operations can have a huge effect on water quality in the marine environment. Sewage and bilge water from ships, storm water runoff, ship paint, oil spill and other port activities can result water pollution and also harm marine life. Dredging for removing sediment from harbor bottom causes habitat destroy, siltation rate change and deoxygenating.

\section{Ports and Water Transportation}

Every day, water transportation transports billions of dollars' worth of products, accounting for more than $90 \%$ (by weight) of worldwide trade [7,8]. In 2015, global seaborne commerce volumes were predicted to have topped 10 billion tonnes [9]. However, the massive volume of global marine traffic is linked to detrimental environmental consequences for the ocean [10]. Marine transportation covers both cargo-carrying and non-cargo commercial shipping (e.g., merchant marine) (e.g., ferries, cruise ships). There were 778,890 bulk carriers (e.g., coal, grains), 75,258 general cargo (multipurpose vessels), 503,343 oil tankers, 244,274 container ships, 44,347 chemical tankers, 5950 ferry and passenger ships, and 1800 liquefied natural gas (LNG) tankers were among the $1,806,650$ principal marine vessels registered in 2016.

More over half of the world's maritime vessels are owned by the top five ship-owning countries (Greece, Japan, China, Germany, and Singapore) [9]. The size and magnitude of global commercial sea transportation were depicted by Halpern [11]. To preserve the marine environment from shipping activities, the International Maritime Organization (IMO) employs a variety of measures. Although the IMO is in charge of global shipping safety and security, it has also acknowledged that marine transportation and port activities have unforeseen environmental consequences. The IMO became increasingly concerned about massive volumes of oil moved by sea in tankers fifty years ago.

The Torrey Canyon Disaster, which spilled 120,000 tonnes of crude oil and killed over 25,000 seabirds and other marine animals in 1967, illustrated the global impact of maritime traffic on the environment [12]. Following that, the IMO established the International Convention for the Prevention of Pollution from Ships (MARPOL) to prevent tanker accidents and minimise their consequences, including pollution prevention during routine operations such as cargo tank cleaning and the disposal of oily engine room wastes. Chemical pollution, packaged goods pollution, sewage, waste pollution, and air pollution are all covered by MARPOL [13]. The United Nations Convention on the Law of the Sea (UNCLOS), ratified in 1994, is one example of international regulation aimed at reducing the environmental implications of marine transportation [14]. Long-term monitoring was utilised to establish the relative changes in impacts in early policy and management measures to mitigate environmental problems related with marine traffic [15]. Marine transportation businesses and port facilities, on the other hand, have built various environmental performance indicator frameworks since the millennium [16].

Many European and North American ports and maritime transportation enterprises (which include shipowners, ports, terminals, shipyards, and shipping companies) have already implemented these frameworks for long-term port management $[17,18]$. Although these performance indicator frameworks are implemented and administered in a variety of worldwide jurisdictions, they all have the same purpose of mitigating environmental impacts by using performance indicators to measure environmental performance. Air quality, water quality, energy consumption, greenhouse gas (GHG) emissions, noise (at sea and at ports), affects on local communities, ship and shore-based rubbish, port expansion, dust, and dredging operations are some of the performance indicators or priorities for shipowners and ports [19].

Regulations and enforcement have been used on a national, regional, and worldwide level to prevent the environmental effects of marine transportation and to guide the maritime industry toward sustainability. Internationally, the IMO restrictions could play a role. The IMO regulations and guidelines, on the other hand, are mostly optional; it is proposed that they become mandatory. It is also suggested that serious rules be enacted, as well as the strict enforcement of existing regulations. Regulating and enforcing regulations aren't the only ways to keep marine transportation under control. Regulations and enforcement procedures may not be effective in forcing the shipping industry to comply with legislation, rules, and standards in the absence of technology solutions [20].

The shipping industry is a leader in clean technology, which is encouraging. Initiatives at the regional and international levels aid in the shaping of the maritime industry. Incentivizing and awarding ships, ports, seaport terminals, and shipyards for their best environmental performance, as well as legislation, enforcement, regional, and worldwide initiatives, can be effective ways to drive the shipping industry toward sustainable shipping. To address the environmental effects of shipping, maritime legislation, 
technical possibilities for solutions, best practise examples, current challenges, and to take preparedness and response actions in advance, the shipping sector must be aware. Other management options to address the environmental effects of marine transportation include educating shipping people about shipping concerns and management solutions, environmental finance for green technologies, and, of course, research and development [21].

Environmental deterioration is affecting oceans all around the world as a result of rubbish pollution caused by ships. For ports and shipowners, a lack of suitable facilities for receiving ship-generated garbage is a big issue. Appropriate waste management strategies, such as the European Union's "The Directive," are critical for reducing the environmental consequences of ports and shipgenerated garbage, as well as providing acceptable vessel receiving facilities. Ship collisions are frequently underreported, and critically endangered species are disproportionately affected [22]. There is no officially acknowledged mitigation outside of the east coast of North America and the Mediterranean Sea. TSSs have been changed, vessel speed limitations have been proposed, and ATBAs have been established to lessen the likelihood of ship strikes in various regions. Regrettably, these techniques are voluntary and not generally used [23]. Furthermore, there is no structure in place to deal with high-seas ship strikes. There have been some promising moves taken, but more must be done.

\section{Ports and Their Environmental Impact}

\section{Pollution of the water supply}

There are numerous models that may be used to quantify the phenomena of pollution dispersion and transport in relation to the hydrodynamic features of sea currents and wind. The US EPA WASP4 Model, for example, is a versatile instrument for analysing a wide range of pollutants in practically any type of water body [24].

There are several sources of water contamination in the port and its environs [25]:

- dry dock operations (accidental discharge of oil and other chemicals in the sea),

- ship destruction (accidental discharge of oil and other chemicals in the sea),

- storm water runoff from port parking lots (organic compounds, fine particle, heavy metals, and so on),

- dredging and escavation of port areas with resuspension of materials and contaminants,

- water stagnation, eutrophication, and anoxia concerns due to low water turnover.

\section{Soil contamination}

There are several sources of soil pollution in the port and its environs [25]:

- spills from bulk handling devices (oil, rubber, etc.) and dust spread during handling (transports between quay and storage area);

- activities on terminals and fuel deposits (accidental discharge of oil in the soil, loss from deposit tankers and pipeline);

- oil and other spills from vehicles degrade the surface, potentially causing a homogenous tarmac to dissolve; heat and heavy loads induce surface settlements;

- chemical spills from ship destruction (see the next paragraph).

\section{Production of wastes}

In the port and its environs, the following primary sources of garbage can be identified:

- dry dock activities (oily and toxic sludges);

- oil terminals and fuel deposits (oily and toxic sludges);

- ships demolition (particularly in India, Bangladesh, Pakistan, and, more likely in the future, China, Vietnam, and the Philippines) due to a near-total lack of facilities for handling waste residues from the demolition process (including heavy metals, PCBs, HFCs, asbestos, and hydrocarbons) [26].

- maintenance and retrofitting of older vessels, also in developed countries. Noise generation sources can be identified in port regions in three main areas:

- cargo movement (from machinery such as quay-crane, pumps, and so on);

- passenger car and heavy vehicle (truck) road traffic (the most important);

- Train traffic noise: Because rail travel in the port and nearby areas is typically moderate speed, the noise level is minimal; nevertheless, in heavily trafficked locations, the problem can be significant.

\section{Pollution in Ports}

Sources of emissions in the port from industrial operations: To take advantage of the proximity of loading and unloading vessels and avoid costly load breakdowns, 
port expansion is usually linked to industrial activity. Power plants, shipbuilding plants, iron and steel plants, nonferrous metal sector, paper and paper pulp facilities, oil refineries, chemical and petrochemical plants, and airports are examples of industrial operations. All industrial activities in ports have a high potential for pollution of the air, water, land, waste, and noise. In the context of an integrated emission inventory strategy, all sources must be analysed. Evaluation of pollutant diffusion air pollution is a problem. Air diffusion models have been developed for the study of coastal areas [27], traditional industrial sites [28], and photochemical pollution [29-31].

\section{Pollution and Aquatic Ecosystems}

Human activities in the water and/or on land have a variety of environmental implications on aquatic ecosystems. Waterborne commercial and passenger transit is one of these worldwide expanding anthropogenic stressors. Cargo ship transports, which include container ships, bulk carriers, and tankers, account for $70 \%$ of total international commerce value [32]. Cruise ships now make up $13 \%$ of the worldwide shipping fleet, although they are predicted to rise in popularity. Shipping emits much less $\mathrm{CO} 2$ per $\mathrm{kg}$ and $\mathrm{km}$ than land- or air-based transportation [33], and it is thus frequently seen as a relatively clean method of transportation $[34,35]$.
Several institutions including the European Commission, the European Union, the OECD [36], the OSPAR Commission [37], the Helsinki Commission [38,39], and the Swedish National Road and Transport Research Institute (SNRTI), have focused on issues of environmental impacts from sea or inland water transportation. The European Commission and the European Parliament, for example, have analysed the external costs of international shipping [40]. Tichavska \& Tovar [41] looked at research that used models to link emissions of air contaminants to affects on human health, which were quantified in monetary terms. Similar models of impacts on aquatic ecosystems, on the other hand, do not exist.

The scientific literature also lacks broad ecosystem studies of shipping's environmental implications [42,43]. Oil spills [44-46], littering by plastics, non-indigenous species (NIS) introduced by ballast water [47], antifouling paints [48,49], and underwater noise [50] are only a few. The numerous environmental consequences of shipping on land and sea, as well as the multiple sources of emissions on the sea, present a significant problem in undertaking an evaluation of the aquatic ecosystem impacts of shipping. In general, shipping and other anthropogenic activities such as air and land-based transportation, industry, and climate change have environmental problems in aquatic settings. Shipping has an impact on the environment in the

\section{Ozone-depleting substances}

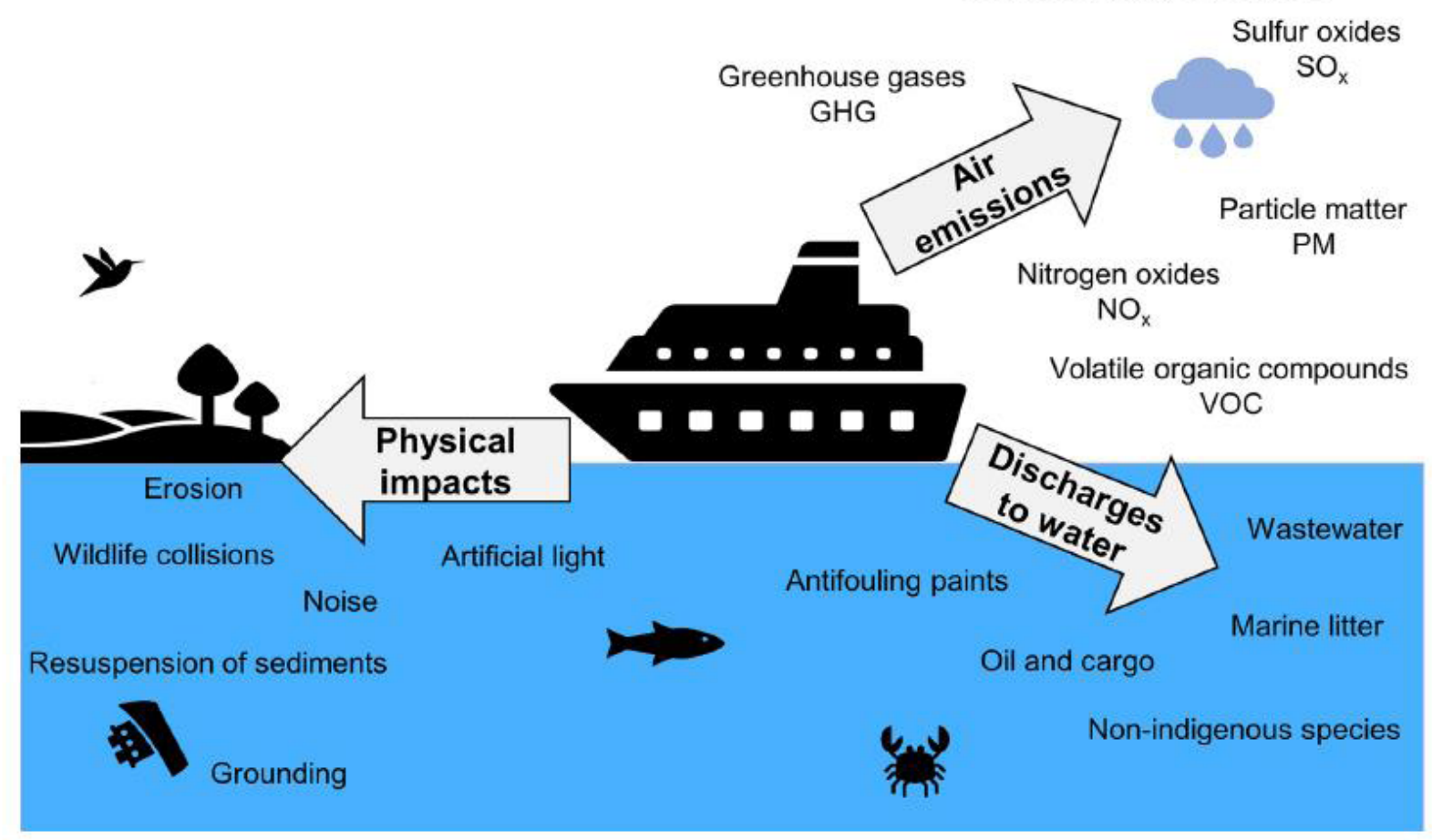

Figure 1: The classification of the environmental impacts of shipping on the aquatic environment into three main categories of discharges to water, physical impact, and air emissions (Jägerbrand, Brutemark, Svedén \& Gren 2019).

Citation: Mesut Selamoglu*. The Effects of the Ports and Water Transportation on the Aquatic Ecosystem. Op Acc J Bio Sci \& Res 10(1)-2021 
aquatic and nearshore habitats, as well as on land and in ports. This research is limited to the environmental and ecological effects of shipping in aquatic and nearshore areas. Air emissions, on the other hand, are deposited both on land and in the aquatic environment. The researchers summarized the classification of the environmental impacts of shipping on the aquatic environment into three main categories of discharges to water, physical impact, and air emissions in their work (Figure 1) [51-53]. As a result, emissions will have an impact on both the aquatic ecosystem and the movement of contaminants from land to water. The study only looks at the environmental effects of marine transport, not harbours, fairway dredging, shipbuilding, or shipbreaking.

\section{Conclusion and Suggestions}

Environmental impact reduction, the technologies to lessen the environmental impact of ship activities, as introduced or addressed primarily by the IMO, are reviewed in the following sections. In addition, methods for reducing pollution by loading and unloading cargo and vehicles from ships will be briefly explored. For additional sources, the idea of best available technologies, as defined by the Council of the European Communities Directive on integrated pollution and preventative control, might be used. Air pollution is a problem. In 1997, the International Maritime Organization established a global sulphur content cap of 4.5 percent $\mathrm{m} / \mathrm{m}$ for fuel oil, as well as provisions allowing for the establishment of special Sulphur Oxides Emission Control Areas with stricter sulphur emission controls (the sulphur content of fuel oil used on board ships does not exceed 1.5 percent $\mathrm{m} / \mathrm{m}$ or an exhaust gas cleaning system is used).

In the Protocol, the Baltic Sea is designated as a Sulphur Oxides Emission Control Area, and the North Sea was designated as a Sulphur Oxides Emission Control Area in the previous the IMO Marine Environment Protection Committee in March 2000. Other marine regions, including ports, can be identified by the Organization following a proposal by contracting States to the Protocol of 1997, provided there is a demonstrated need to avoid, minimise, and regulate air pollution from ship-emitted sulphur oxides. In the same vein, the IMO has approved a technical rule for reducing nitrogen oxide emissions. New diesel engines with a power output of more than $130 \mathrm{~kW}$ that are placed in ships, built on, or have a major modification after January 1,2000 , will be subject to the reductions.

The following nitrogen oxide emissions limitations for diesel engines have been implemented:
- $17.0 \mathrm{~g} / \mathrm{kWh}$ when $\mathrm{n}$ is less than $130 \mathrm{rpm}$

- $45 .{ }^{*} \mathrm{n}-0.2 \mathrm{~g} / \mathrm{kWh}$ when $\mathrm{n}$ is $130 \mathrm{rpm}$ but less than $2000 \mathrm{rpm}$

- $9.8 \mathrm{~g} / \mathrm{kWh}$ when $\mathrm{n}$ is $2000 \mathrm{rpm}$ or more (crankshaft revolutions per minute)

When an exhaust gas cleaning system or another equivalent method is used to reduce onboard nitrogen oxide emissions to the previous defined levels, the running of a diesel engine is permitted.

In the case of ships, an in-depth investigation of methods for decreasing emissions was recently completed as part of the MEET project in terms of primary (reduction of generated emissions) and secondary (abatement systems) control technology available. Sulphur oxides can be controlled using primary means such as lowering fuel sulphur content and secondary methods such as using a scrubber - seawater-washing system. Combustion modification, injection timing retard, modified injectors, Miller systems \& turbocharging with aftercooling, fumigation of intake air, lowering maximum gas temperature in the cylinder, exhaust gas recirculation, non catalytic reduction, fuel substitution, water injection, water/diesel mixture, methanol, clean diesel, new methanol, new methanol, new methanol, new methanol, new methanol, new methanol, new methanol, new pollution of the water supply.

The International Maritime Organization's Marine Environment Protection Committee (MEPC) has formed an anti-fouling Working Group to produce a legislative instrument to control the use of shipboard anti-fouling systems, particularly those containing organotins such as tributyltin (TBT). In November 1999, the IMO Assembly agreed to organise a diplomatic conference in 2001 to adopt the proposed instrument. By January 1, 2003, the instrument should secure a global ban on the use of organotin compounds that act as biocides in anti-fouling systems on ships, and a total ban on the presence of organotin compounds that operate as biocides in antifouling systems on ships by January 1, 2008.

Another MEPC Working Group continued to create new ballast water management requirements. Exchanging ballast water in the deep ocean, where there is less marine life and organisms are less likely to survive, is one of the current strategies for reducing the spread of hazardous aquatic species in ballast water. Other options include various ballast water treatments (filter, thermal, chemical, and radiation) in route to kill the live organisms.

Guidelines giving advice on preferable handling methods 
for various types of liquid products must be developed in order to limit pollution from port operations.

In order to reduce pollution from port operations, a guideline must be developed that includes advice on:

- preferred handling methods for various types of bulk products

- preferred handling methods for different types of bulk items

- Storage strategies that minimise contamination from stored items are desired.

The 1972 Convention on the Prevention of Marine Pollution by Dumping of Wastes and Other Matter prohibits the dumping of certain hazardous materials, necessitates a prior special permit for the dumping of a number of other identified materials, and necessitates a prior general permit for the dumping of other wastes or matter. The purposeful disposal of wastes or other stuff from vessels, aircraft, platforms, or other man-made structures at sea, as well as the deliberate disposal of these vessels or platforms themselves, has been classified as "dumping."

In order for shipowners to establish a waste management plan, IMO MEPC 38 (10 July 1996) finalised a Manual on Shipboard Waste Management. This booklet contains recommendations, technical data, and suggested tools for assessing, developing, and implementing a waste management plan. It was created to meet the International Safety Management (ISM) Code's goal. An MEPC communication group on reception facilities has created draught Guidelines on the provision and use of port trash reception facilities, which will be considered by the Marine Environment Protection Committee. The Guidelines give information on the provision and enhancement of port waste reception facilities, as well as information on the ongoing management of existing facilities and the development and construction of new facilities.

The maritime sector still faces severe challenges in some places due to a lack of reception facilities for polluted ballast water, waste oil, and debris. Trash minimization and pretreatment are emerging as future development sectors, and waste audit is a tool that could also represent a new path. For shipboard volume reduction of plastics, paper, metals, glass, and food waste, treatment methods (compactors, shredders, pulpers, and heat compaction devices) are available. For cruise liners and merchant ships, complete waste treatment systems are available. Manufacturers have created new standards for lowering space needs due to a lack of space for most of the technical installations on board.
A waste treatment strategy should be created to allow for flexible waste treatment and storage. Reduce, reuse, and recycle should be the goal.

The requirement to provide a higher level of comfort to ship passengers and crew as a guarantee of compliance with current noise and vibration standards has prompted shipyards to treat the subject of ship noise seriously in the past year. The shipyard is frequently compelled to take steps in order to deal with ambient and/or structural noise, which necessitates the use of specialised firms. The merely acoustical insulation of the regions of interest is frequently insufficient to ensure the necessary silence, so the research is focused on reducing noise in these areas by properly insulating the sources of noise. The IMO published a Code on Noise Levels on Board Ships in 1982 to encourage and promote noise management at a national level while adhering to internationally agreed-upon norms. Recommended noise levels for specific ship locations were reported in the resolution (crew cabins, offices, recreation rooms, engine control room, etc.). Specific measures, such as preferred taxing and shipping operation modes, preferred taxing and shipping design area, physical ways to prevent noise propagation, and suggestions in port traffic management, must be adopted in order to minimise noise emissions from road and rail traffic in ports.

There are numerous recognised environmental implications of shipping, however there is a scarcity of quantitative data on ecosystem impacts and holistic studies that include all known effects. Additionally, more research is needed on existing and emerging risks to our aquatic environments, like as the increasing number of chemicals transported by water, NIS in conjunction with climate change, and a changing underwater soundscape. Our findings reveal that shipping has a wide range of environmental affects and repercussions, both environmental and ecological. In order for shipping to be as ecologically friendly as possible, such impacts must be examined, evaluated, and reduced. As a result, in transportation planning, the full range of effects must be taken into account. The proposed methodology is beneficial for quantifying pollutant emissions and dispersion in various environmental media. It appears that major efforts in evaluating parameters to quantify emissions in water and soils are required.

Finally, a comprehensive analysis of international pollution control and reduction programmes is presented. These initiatives may not be sufficient, especially in port locations that are typically incorporated into metropolitan areas, in order to prepare for the future rapid growth of maritime transportation. 


\section{References}

1. Commission of the European Communities (1995) Directorate General for transport, Research, Technological Development and demonstration Programme in the field of Transport, Waterborne Transport, Additional information document.

2. Briggs DJ (1993) An integrated emissions inventory for Europe, Final report of feasibility study on behalf of The European Environment Agency Task Force, Institute of Environmental and Policy Analysis, University of Hudderspield, Research Report, No. 93/1.

3. Poulamaa M (2000) NOSE - Nomenclature for sources of emissions, Meeting of the Join Eurostat/EFTA Group, working group "Statistics of the Environment", sub-group "Integrated Emissions Statistics".

4. Council of the European Communities (1996) Council Directive 96/61/ CE concerning integrated pollution and prevention control. Official Journal of the European Communities, N. L 257/26.

5. Organization for Economic Co-operation and Development Pollutant releases and transfer registers (PRTRS) (1996) A tool for environmental policy and sustainable development. Guidance manual for governments, Paris.

6. Trozzi C, Vaccaro R, Trobbiani R, Digiovandomenico P, Piscitello E (1998) Emissions inventory software tools for air quality management plans, Emission Inventory: living in a global environment, December 8-10, 1998, New Orleans.

7. Walker TR (2016) Green Marine: An environmental program to establish sustainability in marine transportation. Marine Pollution Bulletin 105(1): 199-207.

8. IMO (2017) Introduction to IMO.

9. Asariotis R, Benamara H, Hoffmann J, Premti A, Valentine V, et al. (2016) Review of Maritime Transport.

10. Byrnolf S, Lindgren JF, Andersson K, Wilewska-Bien M, Baldi F, et al. (2016) Improving environmental performance in shipping. In K. Andersson, S. Brynolf, J. Fredrik Lindgren, \& M. Wilewska-Bien (Eds.), Shipping and the environment pp. 399-418.

11. Halpern BS, Hengl T, Groll D (2012) Shipping density (commercial). A Global Map of Human Impacts to Marine Ecosystems, showing relative density (in color) against a black background. Scale: $1 \mathrm{~km}$. Wikimedia commons, CC BY-SA 3.0.

12. Wells PG (2017) The iconic Torrey Canyon oil spill of 1967-marking its legacy. Marine Pollution Bulletin 115(1-2): 1-2.

13. IMO (2015) International Convention for the Prevention of Pollution from Ships (MARPOL).

14. UNCLOS (1982) United Nations General Assembly. Convention of the Law of the Sea. 1982.

15. Wooldridge CF, McMullen C, Howe V (1999) Environmental management of ports and harbours-implementation of policy through scientific monitoring. Marine Policy 23(4-5): 413-425.

16. Darbra RM, Pittam N, Royston KA, Darbra JP, Journee H (2009) Survey on environmental monitoring requirements of European ports. Journal of Environmental Management 90(3): 1396-1403.

17. ECOPORTS Valencia (2000) Environmental Management Systems in European Ports. Autoridad Portuaria de Valencia, España: Summary of Proceedings. p. 326.

18. Peris-Mora E, Diez Orejas JM, Subirats A, Ibáñez S, Alvarez P (2005) Development of a system of indicators for sustainable port management. Marine Pollution Bulletin 50(12): 1649-1660.

19. Yakamini R, Chang SC, Smith KS (2017) Noise generation in marine motors. Trans IMarE, 107: 195-207.

20. International Maritime Organization (IMO) (1982) Code of noise levels on board ships, Resolution A.468 (XII).

21. Waller CL, Griffiths HJ, Waluda CM, Thorpe SE, Loaiza I, et al. (2017) Microplastics in the Antarctic marine system: an emerging area of research. Science of the Total Environment 598: 220-227.

22. Srinivasan M, Swain GW (2007) Managing the use of copper-based antifouling paints. Environmental Management 39: 423-441.

23. Ten Hallers-Tjabbes CC, Wegener JW, Van Hattum BAGM, Kemp JF, Ten Hallers E, et al. (2003) Imposex and organotin concentrations in Buccinum undatum and Neptunea antiqua from the North Sea: relationship to shipping density and hydrographical conditions. Marine Environmental Research 55: 203-233.
24. Ambrose RB, Wool TA, Connolly JP (1988) WASP4, A Hydrodynamic and Water Quality Model EPA/600/3-87/039.

25. Speed CW, Meekan MG, Rowat D, Pierce SJ, Marshall AD, et al. (2008) Scarring patterns and relative mortality rates of Indian Ocean whale sharks. Journal of Fish Biology 72: 1488-1503.

26. Veritas DN (2007) Decommissioning of ships, 2007. Environmental protection and ship demolition practices. Report No. 99-3065, Revision No. 03.

27. Chang JC, Han KJ (2000) User's Guide for Offshore and Coastal Dispersion (OCD) model. Version 5. Earth Tech, Inc. on contract of U.S. Department of the Interior, Mineral Management Service, Gulf of Mexico OCS Region.

28. United States Environmental Protection Agency (1995) Compilation of Air Pollutant Emission Factors: Volume I: Stationary Point and Area Sources, AP-42, Fifth Edition.

29. Yamartino RJ, Scire JS, Hanna SR, Carmichael GR, Chang YS (2001) The CALGRID mesoscale photochemical grid model - I. Model Formulation. Atmospheric Environment 26A: 1493-1512.

30. Scire JS, Yamartino RJ, Carmichael GR, Chang YS (2004) CALGRID: A mesoscale photochemical grid model. Volume II: User's Guide.

31. Scire JS, Insley EM, Yamartino RJ, Fernau ME (2005) A User's Guide for the CALMET Meteorological Model.

32. UNCTAD (2017) Review of Maritime Transport 2017. United Nations Conference on Trade and Development (UNCTAD), Geneva.

33. Cristea A, Hummels D, Puzzello L, Avetisyan M (2013) Trade and the greenhouse gas emissions from international freight transport. Journal of Environmental Economics and Management 65: 153-173.

34. Sjödin Å, Flodström E (2007) Environmental Impact of Sea Transportations in the North Sea Region. Annex 1.3.1 to the Final Report. IVL Swedish Environmental Research Institute.

35. Miola A, Paccagnan V, Mannino I, Massarutto A, Perujo A, et al. (2009) External Costs of Transportation, Case Study: Maritime Transports. European Commission Joint Research Centre, Italy.

36. OECD (1997) The Environmental Effects of Freight. OECD, Paris.

37. OSPAR (2009) Assessment of the Impacts of Shipping on the Marine Environment. Monitoring and Assessments SeriesOSPAR Commission.

38. HELCOM (2013) Review of the Fifth Baltic Sea Pollution Load Compilation for the 2013 HELCOM Ministerial Meeting. Baltic Sea Environmental Proceedings No. 141.

39. HELCOM (2018) Maritime activities in the Baltic Sea. Baltic Sea Environment Proceedings No. 152.

40. Maffii S, Molocchi A, Chiffi C (2007) External Costs of Maritime Transport. European Parliament's Committee on Transport and Tourism.

41. Tichavska M, Tovar B (2017) External costs from vessel emissions at port: a review of the methodological and empirical state of the art. Logistics and Transportation Review 37: 383-402.

42. Andersson K, Brynolf S, Lindgren JF, Wilewska-Bien M (2016) Shipping and the Environment: Improving Environmental Performance in Marine Transportation. Springer, Berlin Heidelberg.

43. Walker TR, Adebambo O, Del Aguila Feijoo MC, Elhaimer E, Hossain T, et al. (2019) Environmental effects of marine transportation. In: Sheppard, C. (Ed.), World Seas: An Environmental Evaluation, 2nd edition Academic Press, pp. 505-530.

44. Höfer T (1998a) Tankships in the marine environment. Part I: marine transport of bulk liquids and cargoes split. Environmental Science and Pollution Research, 5: 97-104.

45. Höfer T (1998b) Part II: environmental and health effects resulting from marine bulk liquid transport. Environmental Science and Pollution Research, 5: 231-237.

46. Neuparth T, Moreira SM, Santos MM, Reis-Henriques MA (2012) Review of oil and HNS accidental spills in Europe: identifying major environmental monitoring gaps and drawing priorities. Marine Pollution Bulletin 64: 1085-1095.

47. Bax N, Williamson A, Aguero M, Gonzalez E, Geeves W (2003) Marine invasive alien species: a threat to global biodiversity. Marine Policy 27: 313-323.

48. Konstantinou IK, Albanis TA (2004) Worldwide occurrence and effects of antifouling paint booster biocides in the aquatic environment: a review. Environment International 30: 235-248. 
49. Yebra DM, Kiil S, Dam-Johansen K (2004) Antifouling technology - past, present and future steps towards efficient and environmentally friendly antifouling coatings. Progress in Organic Coatings 50: 75-104.

50. Peng S, Liao H, Zhou T, Peng S (2017) Effects of UVB radiation on freshwater biota: a meta-analysis. Global Ecology and Biogeography 26: 500-510.

51. Jägerbrand AK, Brutemark A, Svedén JB, Gren IM (2019) A review on the environmental impacts of shipping on aquatic and nearshore ecosystems. Science of the Total Environment 695: 133637.

52. ESPO (2012) ESPO Green Guide; Towards excellence in port environmental management and sustainability.

53. United States Environmental Protection Agency (1995) User's Guide for the Industrial Source Complex (ISC3) Dispersion Models. United States Environmental Protection Agency, Research Triangle Park, North Caroline 27711. 